\title{
DUMPING BY STATE-CONTROLLED-ECONOMY COUNTRIES: THE POLISH GOLF CART CASE AND THE NEW TREASURY REGULATIONS
}

Following the conclusion of the Multilateral Trade Negotiations in Geneva earlier this year, ${ }^{1}$ Congress in July passed implementing legislation in the Trade Agreements Act of 1979.2 That Act makes sweeping changes in the administration of the antidumping laws and expressly repeals the Antidumping Act of $1921 .^{3}$ But it leaves untouched those substantive provisions addressed to dumping by state-controlled-economy (SCE) countries, ${ }^{4}$ a subject of continuing controversy in recent years. ${ }^{5}$

1 The agreements were signed by the United States on April 12, 1979, House Comm. on Ways and Means, Trade Agreements Act of 1979, H.R. Rep. No. 317, 96th Cong., 1st Sess. 27 (1979) [hereinafter cited as 1979 H.R. REP.], and President Carter transmitted them to the Congress on June 19. Id. 1. The text of the agreements was published in House CoMm. on Ways and MEANS and Senate Comar. on Finance, 96th Cong., 1st Sess., Multillateral Trade Negotiatrons (Joint Comm. Print, WMCP: 96-18, 1979) [hereinafter cited as MTN AGREEMENTS].

2 Pub. L. No. 96-39, 93 Stat. 144 (July 26, 1979).

3 Id., Title I, § 106 (repealing 19 U.S.C. $\$ \$ 160-173$ (1976)).

4 I9 U.S.C. $\$ 164$ (c) (1976) (repealed, Trade Agreements Act of 1979, Pub. L. No. 96-39, Title I, $\$ 106,93$ Stat. 144 (July 26, 1979); current version at $i d$., Title I, $\S 101$, to be codified as an amendment to the Tariff Act of 1930, at 19 U.S.C. $\$ 1677 \mathrm{~b}(\mathrm{c}))$. See note 23 infra.

The term "state-controlled-economy country" has not been defined. With few exceptions, it has been applied to countries ustually identified as communist. See Anthony, The American Response to Dumping from Capitalist and Socialist Economies-Substantive Premises, and Restructured Procedures After the 1967 GATT Code, 54 Cornelx L. REv, 159, 200-01 (1969).

5 The most recent and comprehensive discussion of dumping by state-controlledeconomy countries, presenting a constellation of views by foremost scholars, practitioners, and bureaucrats in the field, is Interface OnE: Conference Proceedings on the Application of U.S. Antmumping and Countervaming Duty Laws to IMPORTS From STATE-CoNTROLLED ECONOMTES and STATE-OWNED ENTERPRISES (D. Wallace, G. Spina, R. Rawson, \& B. McGill eds. 1979) [hereinafter cited as INTERFACE ONE] (forthcoming). See Anthony, supra note 4; Feller, The Antidumping Act and the Future of East-West Trade, 66 Mich. L. Rev. 115 (1967); Wilczynski, Dumping and Central Planning, 74 J. Pol. Econ. 250 (1966). See also Coudert, The Application of the United States Antidumping Law in the Light of a Liberal Trade Policy, 65 Colum. L. Rev. 189, 224-27 (1965); Fisher, The Antidumping Law of the United States: A Legal and Economic Analysis, 5 LAw \& PoL'Y INT'L Bus. 85, 129-35 (1973); Note, Treasury Runs the Maze: Less than Fair Value Determinations Under the Antidumping Act of 1921, 8 GA. J. INT'L \& Comp. L. 919, 928-29, 936-37 (1978).

For general discussions of United States antidumping law in addition to those cited above, see Barcelo, Antidumping Laws as Barriers to Trade-The United States and the International Antidumping Code, 57 Cornelu L. REv. 491 (1972); Ehrenhaft, Protection Against International Price Discrimination: United States Countervailing and Antidumping Duties, 58 ColvM. L. Rev. 44 (1958); Comment, The Antidumping Act-Tariff or Antitrust Law?, 74 Yane L.J. 707 (1965). 
Dumping occurs when a foreign producer sells his goods in the United States at less than fair value. ${ }^{6}$ If such sales are taking place, and are causing or threatening to cause material injury ${ }^{7}$ to an industry in the United States, or if the sales are materially retarding the establishment of a domestic industry, then an antidumping duty is added with the aim of bringing the United States sale price into line with the fair value of the merchandise. ${ }^{8}$ In an ordinary case, involving goods imported from a market-economy country, the fair value, or foreign market value, is determined by the price at which the foreign producer sells his goods in his home market.9 Alternatively, the test of foreign market value may be the price at which the goods are sold for export to countries other than the United States, ${ }^{10}$ or it may be the constructed value, ${ }^{11}$ computed as the cost of production plus amounts for general expenses and profits. ${ }^{12}$

Special problems arise if these tests for foreign market value are applied to goods imported from state-controlled-economy (SCE) countries. Central planning and the absence of a market structure are widely thought to destroy the usefulness of all three tests as reliable indicators of the value of the goods in question. ${ }^{13}$ In recognition of this problem, Congress enacted section 205(c) of the Trade Act of $1974,{ }^{14}$ which provides that the foreign market value

${ }^{6}$ Trade Agreements Act of 1979, Pub. L. No. 96-39, Title I, $\S 101,93$ Stat. 144 (July 26, 1979) (to be codified as an amendment to the Tariff Act of 1930, at 19 U.S.C. $\$ 1673)$.

7 The requirement that the injury be "material" is a major innovation made by the 1979 Act. See 1979 H.R. REP., supra note 1, at 45-49.

8 Trade Agreements Act of 1979, Pub. L. No. 96-39, Title I, $\$ 101,93$ Stat. 144 (July 26, 1979) (to be codified as an amendment to the Tariff Act of 1930, at 19 U.S.C. $\$ 1673)$.

9 Id. (to be codified at 19 U.S.C. $\$ 1677 \mathrm{~b}(\mathrm{a})(1)(\mathrm{A})$ ).

$10 \mathrm{Id}$. (to be codified at 19 U.S.C. $\$ 1677 \mathrm{~b}(\mathrm{a})(1)(\mathrm{B})$ ).

$11 \mathrm{Id}$. (to be codified at 19 U.S.C. $\$ 1677 \mathrm{~b}(\mathrm{a})(2)$ ).

12 Id. (to be codified at 19 U.S.C. $\$ 1677 \mathrm{~b}(\mathrm{e})$ ).

13 See S. REp. No. 1298, 93d Cong., 2d Sess. 174 (1974) [hereinafter cited as 1974 S. REP], reprinted in [1974] U.S. CoDE Cong. \& AD. NEws 7186, 7311.

14 Pub. L. No. 93-618, Title III, $\$ 321,88$ Stat. 1978 (repealed, Trade Agreements Act of 1979, Pub. L. No. 96-39, Title I, §106, 93 Stat. 144 (July 26, 1979); current version at $i d$., Title $I, \S 101$, to be codified as an amendment to the Tariff Act of 1930 , at 19 U.S.C. $\$ 1677 b(c))$. In its new home at $\$ 773(c)$ of the Tariff Act of 1930 , old $\$ 205(\mathrm{c})$ now reads:

If available information indicates to the administering authority that the economy of the country from which the merchandise is exported is Statecontrolled to an extent that sales or offers of sales of such or similar merchandise in that country or to countries other than the United States do not permit a determination of foreign market value under subsection (a) of this section, the administering authority shall determine the foreign market value of the merchandise on the basis of the normal costs, expenses, and profits as reflected by either-(1) the prices, determined in accordance 
of SCE-country imports is to be determined by looking to the price or constructed value of similar products sold or produced in a third or surrogate non-SCE country.

The interpretation of section 205(c) is of very great importance to many communist countries whose trade with the United States has grown rapidly in recent years. ${ }^{15}$ To date, the chief experience in applying section 205 (c) has been the Polish Golf Cart Case, ${ }^{16}$ an antidumping proceeding that has accordingly assumed a significance extending far beyond the manicured golf links of suburban America. A Polish manufacturer of electric golf carts, produced solely for export to the United States, successfully made inroads into the American market. On the basis of the sales prices of a small Canadian producer, the Polish carts were found to be priced at less than fair value, ${ }^{17}$ and to be injuring the domestic United States industry. ${ }^{18}$ In the duty-assessment stage of the proceedings, however, the Canadian manufacturer's output was no longer deemed sufficient to

with subsection (a) of this section, at which such or similar merchandise of a non-State-controlled-economy country or countries is sold either(A) for consumption in the home market of that country or countries, or (B) to other countries, including the United States; or (2) the constructed value of such or similar merchandise in a non-State-controlled-economy country or countries as determined under subsection (e).

15 From 1967 to 1975, United States imports from Poland increased more than $250 \%$, from $\$ 87.675$ million to $\$ 234.14$ million. Imports from Hungary during the same period multiplied eleven times over, from $\$ 5.699$ million to $\$ 63.710$ million, while the influx of goods from Czechoslovakia, rising from $\$ .98$ million in 1967 to $\$ 37.778$ million in 1975 , is so great as to render percentages meaningless. [1970 1971] Y.B. In'T'L Trade Stats. 31, 167, 628 (United Nations 1973); [1976] I Y.B. INT'L Trade Stats. 289, 442, 718 (United Nations 1977). From 1977 to 1978, imports from these same countries continued to grow: Poland, 33\%; Hungary, 46\%; and Czechoslovakia, 58\%. Office of East-West Policy and Planning, Dep't of Commerce, U.S. Trade Status with Communist Countries 4 (May 24, 1979).

16 The earnest Bluebooker must here confess frustration over his inability to provide the reader with a useful citation. The Polish Golf Cart Case is an interminable proceeding about which very little meaningful information has been published by the authorities involved. Although the Treasury Department duly marks significant events in the Federal Register, e.g., 40 Fed. Reg. 25,497 (1975); 40 Fed. Reg. 11,917 (1975); 39 Fed. Reg. 20,815 (1974), findings of fact and conclusions of law are only hinted at in these notices so that the researcher has the sensation of a quick glimpse through a small keyhole. No improvement can be expected under Trade Agreements Act of 1979, which, although mandating notice of all final determinations, apparently does not require publication of factfindings and legal conclusions. Trade Agreements Act of 1979, Pub. L. No. 96-39, Title I, $\$ 101,93$ Stat. 144 (July 26, 1979) (to be codified as an amendment to the Tariff Act of 1930, at 19 U.S.C. $\$ 1673$ d(d)). See 1979 H.R. REP., supra note 1, at 69 .

A separate antitrust action involving Polish golf carts, Outboard Marine Corp. v. Pezetel, 461 F. Supp. 384 (D. Del. 1978), should not be confused with the antidumping proceeding which is the subject of this Comment.

1740 Fed. Reg. 25,497 (1975).

18 Electric Golf Cars from Poland, 40 Fed. Reg. 49,153 (1975) (U.S.I.T.C. finding of injury to United States industry). 
reflect foreign market value, and the Treasury Department, for lack of any other foreign golf cart manufacturer of adequate size, announced its intention to use the domestic prices of United States manufacturers as the determinant of the competing Polish golf carts' foreign market value. ${ }^{19}$ That predicament elicited howls from Polish trade representatives and catalyzed a rethinking within the Treasury, ${ }^{20}$ which ultimately led to the promulgation of new Treasury regulations in August, 1978. ${ }^{21}$ Under the new regulations, the use of third-country prices and production costs is circumscribed by a requirement that the third country be one at a stage of economic development comparable to that of the exporting SCE country. ${ }^{22}$ In addition, if, as in the Polish case, no comparable market-economy country produces a similar product, a constructed value test may be employed which first ascertains the actual physical inputs in the SCE manufacturer's production process, and then values those inputs in the economic setting of a comparably developed market-economy country. ${ }^{23}$

19 Letter from Carl W. Schwarz, Counsel for Melex USA, Inc., to Representative Charles A. Vanik, Chairman of the Subcomm. on Trade of the House Comm. on Ways and Means (Apr. 27, 1979), reprinted in Multilateral Trade Negotiations: Hearings Before the Subcomm. on Trade of the House Comm. on Ways and Means, 96th Cong., Ist Sess. 734, 735 (1979) [hereinafter cited as 1979 House MTN Hearings].

20 Administration of the Antidumping Act of 1921: Hearing Before the Subcomm. on Trade of the House Comm. on Ways and Means, 95th Cong., $2 \mathrm{~d}$ Sess. 117, 125 (1978) [hereinafter cited as 1978 Antidumping Act Hearing] (statement of Charles Owen Verrill, Jr., Counsel to AMF, Inc., and its wholly owned subsidiary, Harley Davidson Motor Co.).

21 Antidumping Investigation Procedures Under Antidumping Act, 1921, 43 Fed. Reg. 35,262 (1978) (codified at 19 C.F.R. \$153.7 (1979)). Conforming changes were also made to $\$ 153.27$, which specifies the nature of the allegations required in a complaint to the Treasury raising a question of dumping. See 19 C.F.R. \$153.27 (1979). Although this Comment refers to the "September 1978, regulations" in the plural, it focuses solely on the amendments to $\$ 153.7$ and nowhere discusses the technicalities of amended $\$ 153.27$. See text accompanying notes 78-120 infra.

2219 C. F. R. $\S 153.7$ (b) (1979).

23 Id. $\$ 153.7(\mathrm{c})$. The House Report accompanying the Trade Agreements Act of 1979 was careful to avoid expressing any opinion on the Treasury regulations:

Although this report contains the general caveat that this bill is intended to implement only those changes in domestic law which are considered necessary or appropriate to make U.S. law consistent with the international agreements and is not intended as a general expression of approval of current regulations or administrative practice, the Committee believes it is necessary to emphasize the specific application of that caveat to the current law on dumping from non-market economy countries. The reenactment of current statutory provisions on this subject is not an expression of congressional approval or disapproval of the regulations promulgated by the Secretary of the Treasury on August 9,1978 (43 F.R. 35262).

1979 H.R. REP., supra note 1, at 76-77. 
In part I, this Comment briefly reviews the economic theory of the antidumping law, the history of efforts by the Treasury, prior to 1974 , to apply the law to SCE countries, and the problems confronting the SCE producer under section 205(c). Part II develops the facts of the Polish Golf Cart Case, and part III, discussing the controversy surrounding the September, 1978, Treasury regulations, concludes that the regulations are consistent with the statute and based on sound policy considerations.

\section{Antwumping Theory, the Third-Country Test, AND SECTION 205(c)}

\section{A. The Economic Theory of Antidumping Laws}

The classic definition of dumping as "price discrimination between national markets," ${ }^{24}$ was formulated by Jacob Viner in 1923. Specifically, dumping occurs when a foreign producer sells his goods for export to a target market at prices lower than he sells those same goods in his own home market.25 From a theoretical economic viewpoint, dumping, or selling abroad at less than "fair value," is not evil per se..$^{26}$ If a steady stream of goods at differentially low prices could be guaranteed, no harm would ultimately result. Injury to the target market's domestic industry would be more than offset by the benefit of a constant supply of cheap goods. But if the seller cuts short the stream of cheap goods once he has eliminated the target market's domestic competition, and raises the prices of his goods to artificially high and noncompetitive levels, the longrange injury to competition in the target market outweighs the temporary benefit of lower prices.

According to the theory of international free trade, free competition among nations will maximize efficiency and result in lower prices, as each nation specializes in producing those goods for which it is best suited. ${ }^{27}$ Short-run or predatory dumping of the kind just described, because it derails this "natural law" of comparative advantage, constitutes an unfair international trade practice, against which nations espousing free trade principles may legitimately defend themselves. Significantly, however, to avoid a protectionist result, laws designed to combat dumping must not place sanctions

24 J. Vinen, Dumping: A Problem in Internationad Trade 3 (1923).

25 Anthony, supra note 4, at 159.

26 For a short discussion of the economics of dumping, see id. 163-77. J. VINER, supra note 24 , is still the major authority on the subject.

27 See, e.g., P. SAMUELson, Economics 668-91 (10th ed. 1976); Anthony, supra note 4 , at $163-77$. 
on all imports that undersell domestic goods, ${ }^{28}$ but only on those imports that undersell domestic goods by exploiting an artificial or anticompetitive advantage. Price-discriminatory exports are taken to indicate just such an artificial advantage, on the assumption that the lower export prices are subsidized by higher prices in the dumper's home or other markets and thus do not reflect the fair value of the goods, understood as cost plus profit. ${ }^{29}$

Thus, the real cost of the imported goods, whether reflected by home market prices, export prices, or some hypothetical construction, must be the touchstone of any investigation to determine whether dumping has occurred. When cost or price data are unobtainable or unreliable, the conventional economic theory underlying antidumping laws breaks down, and attempts to discover the value of imported goods may degenerate into mere speculation.

\section{B. Application of the Antidumping Act to State-Controlled- Economy Countries Prior to 1974}

State-controlled-economy (SCE) countries present special problems for the calculation of foreign market value. The normal tests, based on the price in the home market, the export price to countries other than the United States, or the constructed value, all presuppose a free market in which prices are set by the rise and fall of supply and demand. In a planned economy, however, home market prices are fixed by governmental authorities on the basis of production or import goals and projected demand elasticity, ${ }^{30}$ and need not ultimately reflect the true costs of production. Export prices to countries other than the United States may give no better clue to actual production costs in an SCE country because they, too, are likely to be determined by noneconomic influences. ${ }^{31}$ As with prices, the attempt to arrive at actual costs by means of a constructedvalue test encounters the fundamental difficulty of ascertaining values in a nonmarket economy.

28 In theory, a foreign manufacturer could dump his goods in the United States even though he sold them at prices equal to or higher than his United States competitors. Dumping that does not undersell domestic prices has been labeled "technical dumping" and will not result in a finding of injury. See, e.g., Vinyl Clad Fence Fabric from Canada, 40 Fed. Reg. 51,243, 51,244-45 (1975) (concurring statement of reasons of Comm'rs Moore and Ablondi).

29 See Anthony, supra note 4, at 166-77.

30 Feller, supra note 5, at 118.

31 Id. 128. 
When the Antidumping Act of 1921 was adopted,32 dumping by SCE countries was not a pressing problem. The only SCE country then existing, the Soviet Union, was still in its infancy, and the Act understandably contained no provisions concerning economies not organized on free market principles. As market-economy countries and SCE countries alike became interested during the 1950s in increased East-West trade, the shortcomings of the 1921 Act soon became apparent.

In the first case in which imports from an SCE country were found to be selling at less than fair value, Bicycles from Czechoslovakia, ${ }^{33}$ Treasury employed neither the home market price nor the export price nor the constructed value. In their place, a new "third-country" ${ }^{34}$ test was applied, which looked to the home market or export price of similar merchandise produced in a non-SCE country..$^{35}$ In Jalousie-Louvre-Sized Sheetglass from Czechoslovakia, ${ }^{36}$ the third-country price test was made explicit, and the possibility of using a constructed-value test was rejected because of an asserted lack of data on costs, expenses, and profits.

Authority for this rejection of the statutory methods of calculation was eventually offered in Portland Cement from Poland, ${ }^{37}$ in which the Treasury concluded that sales in an SCE country do not qualify as sales "in the ordinary course of trade" as required by the Act. ${ }^{38}$ Such an interpretation found support in J.H. Cottman \& Co. v. United States, ${ }^{39}$ a decision of the Court of Customs and Patent Appeals holding that the "ordinary course of trade" referred to conditions in a free market economy, where competitive forces are allowed to operate without restriction. ${ }^{40}$

$32 \mathrm{Ch} .14$, Title II, $\S \S 201-212,42$ Stat. 11 (1921) (repealed Trade Agreements Act of 1979, Pub. L. No. 96-39, Title I, $\$ 106,93$ Stat. 144 (July 26, 1979); current version at id., Title I, $\S 101$, to be codified as an amendment to the Tariff Act of 1930 , at 19 U.S.C. $\$ \$ 1671-1677 \mathrm{~g}))$.

3325 Fed. Reg. 6657 (1960).

34 The term "third country" is used in this Comment to refer to the selection of a surrogate market-economy country for the purpose of valuing imports from an SCE country. It should not be confused with the test of foreign market value, which looks to the export price to countries other than the United States and which shall be referred to as the export-price test.

35 See Feller, supra note 5, at 130 n.65.

3627 Fed. Reg. 8457 (1962).

3728 Fed. Reg. 6660 (1963).

3819 U.S.C. $\$ 164$ (a) (1976) (repealed, Trade Agreements Act of 1979, Pub. L. No. 96-39, Title I, $\S 106,93$ Stat. 144 (July 26, 1979); current version at id., Title I, $\$ 101$, to be codified as an amendment to the Tariff Act of 1930 , at 19 U.S.C. $\$ 1677 \mathrm{~b}(\mathrm{a})(1)(\mathrm{A}))$.

3920 C.C.P.A. 334, 357 (1932), cert. denied, 289 U.S. 750 (1933).

40 See Feller, supra note 5 , at 126. 
The third-country test was used consistently during the $1960 \mathrm{~s}^{41}$ Occasionally, adjustments were allowed for differences in transportation costs, quality, and productive efficiency. ${ }^{42}$ As trade with SCE countries continued to increase, however, Treasury's ad hoc treatment of the problem was brought to the attention of Congress. The result was section 205(c) of the Trade Act of 1974..33

\section{Section 205(c) of the Trade Act of 1974}

Section 205(c) enacted the Treasury's third-country test into law. If the Secretary finds that the exporting economy is statecontrolled to the extent that foreign market value cannot be calculated by the ordinary tests, ${ }^{44}$ he may employ:

(1) the prices . . . at which such or similar merchandise of a non-state-controlled-economy country or countries is sold either (A) for consumption in the home market of that country or countries, or (B) to other countries, including the United States; or

(2) the constructed value of such or similar merchandise in a non-state-controlled-economy country or countries .45

Although section 205(c) itself stated no preference, prior Treasury practice tended to rely on third-country prices and not on constructed values. ${ }^{46}$

Like the Treasury's ad hoc third-country price test, the price test option embodied in section 205(c) confronts the SCE exporter with substantial uncertainties not faced by his capitalist counterpart. Imagine an SCE exporter who wishes to sell his product in the United States for $\$ 100$. A similar domestic United States product sells for $\$ 140$, and similar West German merchandise costs the United States consumer $\$ 135$. A Japanese firm sells the same article for consumption in Japan for only $\$ 99.47$ Depending on which foreign country is selected by the Treasury as the third country, the foreign market value of the SCE exporter's product may range from

41 Anthony, supra note 4 , at 200 \& n.169.

42 E.g., Cast Iron Soil Pipe and Fittings from Poland, 32 Fed. Reg. 2901 (1967); Shoes from Czechoslovakia, 31 Fed. Reg. 1207, 7087 (1966).

43 Pub. L. No. 93-618, Title III, $\$ 321,88$ Stat. 1978 (repealed, Trade Agreements Act of 1979, Pub. L. No. 96-39, Title I, $\$ 106,93$ Stat. 144 (July 26, 1979); current version at $i d$., Title $I, \S 101$, to be codified as an amendment to the Tariff Act of 1930, at 19 U.S.C. $\$ 1677 \mathrm{~b}(\mathrm{c}))$.

44 Id.

45 Id.

*6 Anthony, supra note 4 , at 200-05.

47 This hypothetical is adapted from remarks of Professor Stanislaw J. Soltysinski in INTERFACE ONE, supra note 5, at 97. 
$\$ 99$ to $\$ 135$. Unlike the market-economy exporter who enjoys a reasonable assurance that the foreign market value of his products will be determined by his home market prices or his export price to other countries-prices which he surely has knowledge of and over which he exerts control-the SCE exporter has no way of knowing whether he is dumping until an antidumping proceeding gets under way. ${ }^{48}$

The unfairness of selectively imposing these risks on SCE exporters is further magnified by an ambiguity in the language of section 205(c), which can be read to allow selection of the United States as the third country whose home market or export price is determinative of foreign market value. Thus, in the illustration above, the Treasury would be free to find the United States manufacturer's price of $\$ 140$ as the price "at which such or similar merchandise of a non-state-controlled-economy country [the United States] . . . is sold . . . for consumption in the home market " 49 Unless used with restraint, such a construction of the Act, although perhaps supported by the legislative history, ${ }^{50}$ is

48 Congress in 1974 did express concern for the predicament of foreign producers who risk antidumping duties on the basis of prices charged by others and over which they have no control, and accordingly amended $\$ 212(3)$ of the Antidumping Act to eliminate from the definition of "such or similar merchandise" merchandise "produced by another person." See 19 U.S.C. $\S 170(\mathrm{a})$ (1976) (repealed, Trade Agreements Act of 1979, Pub. L. No. 96-39, Title I, $\$ 106,93$ Stat. 144 (July 26, 1979); current version at $i d$., Title I, $\$ 101$, to be codified as an amendment to the Tariff Act of 1930, at 19 U.S.C. $\$ 1677(16)$ ); 1974 S. ReP., supra note 13, at 177, reprinted in [1974] U.S. CODE Cong. \& AD. News 7186, 7314; H.R. REP. No. 571, 93d Cong., 1st Sess. 72 (1973) [hereinafter cited as 1973 H.R. REP.].

Counsel for Melex USA, Inc., the American subsidiary of the Polish golf cart manufacturer, concocted the ingenious argument that this redefinition must be read into $\$ 205$ (c), with the result that the third-country-price test can only be employed if the SCE producer is producing goods in a market-economy country, as, for example, if Poland began manufacturing golf carts in a plant in Spain. Comments of Melex USA, Inc., on Proposed Amendments Pertaining to Merchandise from State-Controlled-Economy Countries 7-8 (Feb. 22, 1978) [hereinafter cited as Melex Comments] (copy on file with the University of Pennsylvania Law Review). Although the argument is technically a compelling one, it is readily apparent that strict application of the rules of construction here produces an absurd result. Congress, in endorsing Treasury's existing practice of applying a thirdcountry-price test, could hardly have meant to confine its use in the future to a situation never before encountered.

4919 U.S.C. $\$ 164$ (c) (1976) (repealed, Trade Agreements Act of 1979, Pub. L. No. 96-39, Title I, \$106, 93 Stat. 144 (July 26, 1979); current version at id. Title I, $\$ 101$, to be codified as an amendment to the Tariff Act of 1930, at 19 U.S.C. $\$ 1677 b(c))$.

50 The Senate Report, referring to $\$ 205(\mathrm{c})$, expressly noted:

The amendment is intended to permit comparison of the purchase price or exporters' sales price of the merchandise in question with the prices of such or similar merchandise produced in the United States in the absence of an adequate basis for comparison using prices in other non-State-controlledeconomy countries. 
patently protectionist. Freewheeling use of domestic United States prices as the standard of fair value effectively eliminates competition by SCE imports. Because the exporter's costs of packaging, shipping, and insurance would have to be added to the United States manufacturer's price, ${ }^{51}$ the imported goods would have to be sold at higher prices than the domestic variety.

On its face, section 205(c) puts the SCE producer at a further disadvantage because it does not provide for adjustments based on proven economies. ${ }^{52}$ An efficient producer in a free market economy can avoid antidumping duties and reap the benefit of his lower costs by evenhandedly selling at low prices in his home market as well as in the United States. No matter how efficient or evenhanded the SCE exporter, the Trade Act of 1974 does not expressly provide that his efficiency shall be taken into account. The "value" of his goods will be determined, not by reference to his costs or his sales, but by reference to the sales or costs of an undetermined, possibly less efficient manufacturer in a third country.

These problems with the application of section 205(c) 's foreign market value tests to SCE countries-the gross uncertainty, the possibly unrestrained use of United States domestic prices, and the omission of provisions permitting cost-justified adjustments-all derive from a common source: the failure to assure that the resulting foreign market value reflects the true costs of production. Such a departure from cost considerations creates havoc because it runs counter to the basic principles underlying United States antidumping law. That law was intended to prevent unfair competition by prohibiting predatory dumping, not to protect United States in-

1974 S. ReP., supra note 13, at 174, reprinted in [1974] U.S. CoDE CONG. \& AD. News 7186, 7311. The House Report did not take a position on this issue. See 1973 H.R. REP., supra note 48, at 157. For the view that the quoted sentence in the Senate Report was "a gratuitous addition ... which had, and has, absolutely no basis in fact or law," see Melex Comments, supra note 48, at 13.

Prior to the promulgation of the September, 1978, regulations, the regulation in force provided that United States prices or constructed value "generally will be utilized" where sales in market-economy countries other than the United States "do not provide an adequate basis for comparison." 19 C.F.R. $\$ 153.7$ (1978). For the full text of the pre-1978 regulation, see note 89 infra. It is unclear, however, whether the Treasury ever used domestic United States prices as a determinant of foreign market value prior to 1974. See 43 Fed. Reg. 35,262, 35,264 (1978).

51 Letter from Stanislaw J. Soltysinski, Special Counsel to Pezetel, to Robert H. Mundheim, General Counsel, Department of the Treasury (Aug. 25, 1977) [hereinafter cited as Soltysinski Letter] (copy on file with the University of Pennsylvania Law Review). Contra, 1978 Antidumping Act Hearing, supra note 20, at 117,122 (statement of Charles Owen Verrill, Jr.).

52 INTERFACE ONE, supra note 5, at 75, 82 (address by Deputy Assistant Treasury Secretary Peter D. Ehrenhaft); id. 98 (remarks of Professor Stanislaw J. Soltysinski). 
dustry from efficiently made, lower-priced imports. ${ }^{53}$ Without a method for approximating the SCE exporter's actual costs, any determination of the foreign market value of his goods is necessarily arbitrary. The tests contained in section 205(c), because they may be applied without regard to actual costs, do not adequately restrain the potential use of antidumping law as a protectionist barrier to East-West trade.

Focus on these issues of valuation sharpened in the Polish Golf Cart Case and eventually resulted in the promulgation of new regulations.

\section{The Polish Golf Cart Case}

Beginning in 1971, Poland began to export to the United States its Melex golf carts, designed on the model of the E-Z Go cart made by Textron, Inc., the number one United States manufacturer..$^{54}$ In 1974, nearly seven thousand Melex carts were sold, accounting for twelve percent of all golf carts sold in this country. ${ }^{55}$ In April of that year, Harley Davidson Motor Co., Inc., the second largest domestic manufacturer of golf carts, ${ }^{56}$ filed with the Treasury Department a complaint alleging that Pezetel, the Polish manufacturer, was selling its golf carts in the United States at less than fair value. ${ }^{57}$ Shortly thereafter, Treasury announced the institution of an inquiry into the charges, ${ }^{58}$ followed in March, 1975, by a notice of withholding of appraisement, ${ }^{59}$ a procedure mandated by its finding that reasonable grounds existed for suspecting that the Polish golf carts were being sold at less than fair value. Finally, on June 11, 1975, Treasury announced that its reasonable suspicions had hardened into a firm determination of less-than-fair-value sales. ${ }^{60}$

Over the objections of Harley Davidson, Treasury's calculation of the foreign market value of Melex golf carts in this initial phase of the proceedings was based on the 1974 sales of a small Canadian

531974 S. REP., supra note 13, at 179, reprinted in [1974] U.S. CodE CoNG. \& AD. NEws 7186, 7316.

541978 Antidumping Act Hearing, supra note 20, at 123-24 (statement of Charles Owen Verrill, Jr.).

55 Electric Golf Cars from Poland, 40 Fed. Reg. 49,153 (1975). note 19.

${ }^{56}$ Letter from Carl W. Schwarz to Representative Charles A. Vanik, supra

571978 Antidumping Act Hearing, supra note 20, at 122 (statement of Charles Owen Verrill, Jr.).

5839 Fed. Reg. 20,815 (1974).

5940 Fed. Reg. 11,917 (1975). The notice, in effect, directed customs officers to postpone determinations of the tariff to be levied on Polish golf carts entering the country, pending the outcome of the antidumping proceeding.

6040 Fed. Reg. 25,497 (1975). 
manufacturer, Marathon Golf Car Co., Ltd. ${ }^{\text {11 }}$ Harley Davidson urged Treasury to use the higher sales prices of domestic United States manufacturers. For its part, Pezetel, also unhappy with Treasury's methodology, complained that Treasury ignored two independent studies of the constructed value of Polish golf carts as produced under Canadian conditions; both studies showed that the carts were not being dumped. ${ }^{2}$ The Treasury's calculations, according to Pezetel, while concededly allowing a small adjustment for economies of scale, ${ }^{63}$ failed to take into account the significantly lower labor costs in Poland. ${ }^{64}$ Notwithstanding these objections, Treasury calculated foreign market value on the basis of the Canadian manufacturer and found substantial dumping margins, in some cases exceeding twenty percent, for all Melex sales in 1974.65

In September of 1975, the International Trade Commission found that the less-than-fair-value sales of Polish golf carts had injured the domestic industry, ${ }^{66}$ and the case entered the duty-assessment stage.

No duties were liquidated until mid-1977, when Treasury, on the basis of the 1974 Marathon prices adjusted for inflation, ${ }^{67}$ assessed duties of up to $\$ 155$ per cart for the first eight months of 1975 and collected more than $\$ 600,000.68$ Although the question has been disputed, it appears that by 1976, Marathon's production of golf carts no longer sufficed to form the basis of a foreign market value determination for the continuing influx of Melex golf carts. ${ }^{69}$ At first indicating that duties for the first three quarters of 1976

611978 Antidumping Act Hearing, supra note 20, at 123. Marathon produced approximately 200 golf carts in $1974, \mathrm{id}$., in comparison with Pezetel's production capacity of 10,000 per year. Id. 129. Counsel for Melex referred to Marathon as a "Mom and Pop" producer of "custom made" golf carts. Letter from Carl W. Schwarz to Representative Charles A. Vanik, supra note 19.

62 Soltysinski Letter, supra note 51.

63 Id. Contra, 1978 Antidumping Act Hearing, supra note 20, at 123 (statement of Charles Owen Verrill, Jr., alleging that Treasury granted a substantial reduction for economies of scale).

64 Soltysinski Letter, supra note 51.

65 Electric Golf Cars from Poland, 40 Fed. Reg. 49,153, 49,154 (1975).

${ }^{66} I d$.

67 Comments of Harley Davidson Motor Co. on Proposed Amendments Pertaining to Merchandise from State-Controlled-Economy Countries 8 (Feb. 16, 1978) [hereinafter cited as Harley Davidson Comments] (copy on file with the University of Pennsylvania Law Review).

68 Id.

69 Counsel for Harley Davidson alleged that Marathon had ceased producing golf carts and had only nominal sales of a utility vehicle that was similar in design. 1978 Antidumping Act Hearing, supra note 20, at 125 (statement of Charles Owen Verrill, Jr.). Counsel for Pezetel insisted that Marathon was not going out of business, but instead had nearly doubled its 1974 sales in 1976. Soltysinski Letter, supra note 51. 
would again be assessed on the basis of adjusted 1974 Canadian sales, $^{70}$ Treasury later reversed itself, yielding to Harley Davidson's persistent contention that the domestic prices of a United States manufacturer should be the referent for the foreign market value of the Polish golf carts. ${ }^{71}$

This result vexed the Poles, who argued forcefully that use of domestic United States prices would effectively bar Melex carts altogether. When the additional costs of ocean freight, insurance, and normal duties were taken into account, Pezetel would be required to sell its golf carts at prices substantially higher than those of United States models. ${ }^{72}$ That anomaly was not lost on Treasury officials, ${ }^{73}$ and discussions within the Treasury Department and with Polish trade representatives led eventually to proposal of new regulations in January, $1978 .^{74}$ On September 8, 1978, those proposed regulations, with modifications, became effective. ${ }^{75}$

The brief history recounted here suffices to show that prior to the September, 1978, regulations, the Polish manufacturer faced an American bureaucratic nightmare of Kafkaesque dimensions. The extreme injustice of using domestic United States prices as the test of the foreign market value of Melex carts only compounded the unfairness of computing the carts' value without regard to the claimed cost and production advantages achieved by Pezetel's efficient operation. ${ }^{76}$ Moreover, Pezetel confronted the uncertainty of not knowing from week to week how the value of its golf carts would be measured. In the words of Pezetel's special counsel:

In short, for the last three years, Pezetel has been confronted with endless shifting and unclear interpretations of the applicable statute, and unfair and arbitrary resolutions

70 Letter from Treasury Secretary W. Michael Blumenthal to Representative Henry S. Reuss (Nov. 28, 1977), quoted in Harley Davidson Comments, supra note 67 , at $8-9$.

71 Letter from Carl W. Schwarz to Representative Charles A. Vanik, supra note 19. No duties have yet been liquidated under this standard.

72 Soltysinski Letter, supra note 51.

73 Letter from Deputy Assistant Treasury Secretary Peter D. Ehrenhaft to Representative Henry S. Reuss (Dec. 28, 1977), quoted in Harley Davidson Comments, supra note 67 , at 8-9.

7443 Fed. Reg. 1356 (1978).

7543 Fed. Reg. 35,262 (1978). The Poles attempted to persuade Treasury to apply the new regulations retroactively to 1975 , a move which, if successful, would have avoided heavy duties during 1975-1978 based on United States manufacturers' prices. Treasury appears to have taken a firm stand that the regulations may only be applied to goods entering the country after September 8, 1978, the date when the regulations took effect. See 1978 Antidumping Act Hearing, supra note 20 , at $117,126-27$.

70 Soltysinski Letter, supra note 51. 
of the factual issues under that statute. As a result, it is now utterly impossible for Pezetel (and the whole of Polish industry) to determine what is required of it by American law, or to know whether or not it is considered to be dumping. In fact, in the past six months, various Customs officials have given Pezetel estimates of foreign market value ranging from $\$ 643$ to $\$ 1300 .^{77}$

\section{The September, 1978, Treasury Regulations}

The new regulations promulgated by the Treasury, ${ }^{78}$ effective September 8,1978 , go a long way towards solving the problems with

$\pi 7$ Id.

7819 C.F.R. $\$ 153.7$ (1979):

(a) General. If the information available indicates to the Secretary that the economy of the country from which the merchandise is exported is state-controlled to an extent that sales or offers of sales of such or similar merchandise in that country or to countries other than the United States do not permit a determination of fair value under $\$ 153.2, \S 153.3$, or $\$ 153.4$, the Secretary shall determine fair value on the basis of the normal costs, expenses, and profits as reflected by either:

(1) the prices, determined in accordance with subsection 205 (a) and section 202 of the Act (19 U.S.C. 164(a), 161) at which such or similar merchandise of a non-state-controlled economy country or countries is sold either: (i) For consumption in the home market of that country or countries, or (ii) to other countries, including the United States; or

(2) The constructed value of such or similar merchandise in a nonstate-controlled-economy country or countries.

(b) Comparability of economies. (1) The prices as determined under $\$ 153.7(\mathrm{a})(1)$, or the constructed value as determined under $\$ 153.7$ (a) (2), shall be determined, to the extent possible, from the prices or costs in a non-state-controlled-economy country or countries at a stage of economic development comparable to the state-controlled-economy country from which the merchandise is exported. Comparability of economic development shall be determined from generally recognized criteria, including per capita gross national product and infrastructure development (particularly in the industry producing such or similar merchandise).

(2) If no non-state-controlled-economy country of comparable economic development can be identified, then the prices or constructed value as determined from another non-state-controlled-economy country or countries other than the United States shall be used.

(3) If neither $\$ 153.7(\mathrm{~b})(\mathrm{I})$ nor (b) (2) provides an adequate basis for determining the price or constructed value of such or similar merchandise, then the prices or constructed value, as determined from the sales or production of such or similar merchandise in the United States, shall be used.

(c) Use of constructed value. If such or similar merchandise is not produced in a non-state-controlled-economy country which is concluded to be comparable in terms of economic development to the state-controlledeconomy country from which the merchandise is exported, the constructed value of such or similar merchandise may be determined from the costs of specific objective components or factors of production incurred in producing the merchandise in question, including, but not limited to, hours of labor required, quantities of raw materials employed, and amounts of energy consumed, if such information is obtained from the producer of the merchandise in the state-controlled-economy country under investigation, and verification of such information in the state-controlled-economy country is 
section 205(c) so pointedly raised by the Polish Golf Cart Case. They begin by stating that price or constructed value shall be computed from cost and price data in a market-economy country at a stage of development comparable to the exporting SCE country. ${ }^{79}$ If no comparable market-economy country can be found, the price or constructed value shall be measured by data taken from a noncomparable market-economy country other than the United States. ${ }^{80}$ If that option fails to provide an adequate basis for determining foreign market value, then, and only then, will the Treasury resort to United States domestic prices or costs. ${ }^{81}$

With respect to constructed value, the regulations provide that the SCE manufacturer may furnish data on the "specific objective components" of production, such as hours of labor, quantities of raw materials, and amounts of energy consumed. These components, if verified, will then be valued in a comparable non-statecontrolled-economy country. Two criteria of comparability specifically endorsed by the regulations are per capita gross national product and infrastructure development. ${ }^{82}$

Although the new regulations do not eliminate the hazards of unpredictability inherent in the statute, they mark a significant advance. Where before the Treasury was free to select any third country as the benchmark of fair value, now the choice is limited, to the extent possible, to third countries of comparable economic development. However uncertain the concept of comparability may be in theory, ${ }^{83}$ the regulations give hope of a case-law development which, in practice, will provide increasingly concrete and trustworthy guidelines to the SCE exporter.

The explicit constraints placed by the regulations on the use of United States domestic prices and cost figures constitute a second advance. Although the regulations do not discard this test altogether, a step that would probably have violated the intent of

concluded to the satisfaction of the Secretary. Such components or factors shall be valued and such values verified in a non-state-controlled-economy country determined to be reasonably comparable in economic development to the state-controlled-economy country under investigation. To the values thus obtained, there shall be added an amount for general expenses and profits, as required by section 206(a)(2) of the Act (19 U.S.C. 165 (a) (2)), and the cost of all containers and coverings and other expenses, as required by section 206(a)(3) of the Act (19 U.S.C. 165(a)(2)). 7919 C.F.R. $\$ 153.7(b)(1)$ (1979).

$80 \mathrm{Id}$. $\$ 153.7(\mathrm{~b})(2)$.

81 Id. $\$ 153.7(\mathrm{~b})(3)$.

82 Id. $\$ 153.7$ (c).

83 See text accompanying notes $108-20$ infra. 
Congress, ${ }^{84}$ they make its use highly improbable. The only conceivable situation in which an SCE exporter would be threatened with a finding of foreign market value based on United States manufacturers' domestic prices or costs would be one in which a) no comparably developed economy could be found which produced similar merchandise, and b) a constructed value based on the exporter's own production factors could not be calculated because the exporter refused to come forward with the applicable data. In this new setting, then, the domestic United States price or constructedvalue tests will serve as a useful spur to disclosure by SCE producers.

A third advantage of the 1978 regulations is the use of data on the "specific objective components" of production in the SCE country, an innovation "which recognizes both natural advantages and possible disadvantages of production for the producer." 85 Under the old regulation, an efficient SCE exporter ran the risk of being saddled with a valuation based on the prices of an inefficient third-country manufacturer. Although he might produce an item with one-half the manpower costs required by the inefficient thirdcountry manufacturer, computation of the foreign market value would ignore the SCE exporter's "specific objective components" of production and thus overlook his efficient use of labor. The amended regulations, to the extent they permit use of constructed value based on actual physical inputs, place the SCE exporter on a more equal footing with his market-economy competitors.

The language of the new regulations, ${ }^{86}$ and the Customs Service protestations, ${ }^{87}$ leave no doubt that price tests will continue to enjoy official preference over constructed value. Nevertheless, in practice, constructed value will enjoy increased use. Under amended section 153.7 (c),${ }^{88}$ constructed value may be employed whenever prices of identical or similar merchandise from a comparable economy are not available; in the past, no strict comparability rule limited the use of the price test. ${ }^{89}$ Differences in trade behavior between SCE

84 See note 50 supra.

8543 Fed. Reg. 35,262, 35,264 (1978). See text accompanying note 52 supra.

86 See note 78 supra.

87 "The regulations as adopted should make it clear that costs of production in a non-state-controlled-economy country of comparable economic development will be used only if . . . [p]rice information is unavailable . . ." 43 Fed. Reg. 35,262, 35,264 (1978).

8819 C.F.R. $\$ 153.7$ (c) (1979).

891979 House MTN Hearings, supra note 19, at 106, 109 (statement of Charles Owen Verrill, Jr.). Prior to the September, 1978 amendments, $\$ 153.7$ read as follows: 
countries and market-economy countries may also work to favor use of constructed value. Most SCE countries, because of central planning, are better able than are market-economy countries at comparable stages of development to channel resources into the manufacture of products specially for export to the United States. Consequently, the advent of the comparable-economy concept may serve to establish constructed value, based on actual physical inputs, as the principal determinant of foreign market value. Because the constructed-value method offers the SCE exporter a more realistic valuation of his goods, ${ }^{90}$ this development should exert a beneficial influence on administration of the antidumping law and the future of East-West trade.

\section{A. Statutory Objections}

Opponents of the new regulations raised two major arguments against them, one statutory and the other economic. First, they contended that the amended regulations were inconsistent with section 205(c) of the Trade Act of 1974. Second, they questioned the theoretical soundness of the concept of comparably developed economies, specifically ridiculing the underlying presumption that economies comparable in macroeconomic terms are also microeconomically similar.

Significantly, the statutory arguments do not rest on the wording of section 205(c), ${ }^{81}$ which neither expressly nor impliedly contra-

If the information available indicates to the Secretary that the economy of the country from which the merchandise is exported is state-controlled to an extent that sales or offers of sales of such or similar merchandise in that country or to countries other than the United States do not permit a determination of fair value under $\$ \S 153.2,153.3$, or 153.4 , the Secretary shall determine fair value on the basis of the normal costs, expenses, and profits as reflected by either:

(a) The prices, determined in accordance with section 205 (a) and section 202 of the Act (19 U.S.C. 164(a), 161), at which such or similar merchandise of a non-state-controlled-economy country or countries, including the United States, is sold either (1) for consumption in the home market of that country or countries, or (2) to other countries, including the United States; or

(b) The constructed value of such or similar merchandise in a nonstate-controlled-economy country or countries, including the United States, as determined under section 206 of the Act (19 U.S.C. 165).

The prices or the constructed value of the United States produced merchandise generally will be utilized where sales or offers for sale of such or similar merchandise in any other non-state-controlled-economy country do not provide an adequate basis for comparison.

19 C.F.R. $\$ 153.7$ (1978).

90 InTERface ONe, supra note 5, at 98 (remarks of Professor Soltysinski).

91 See note 14 supra. 
dicts the new regulations. Instead, the opponents of the regulations, drawing inferences from the legislative history and the past administration of the antidumping law, purported to show that the regulations violate the intent of Congress.

The chief premise of the statutory argument is that by enacting section 205(c), Congress meant to ratify the existing Treasury practice with respect to SCE countries. That practice, as expressed in the pre-1974 regulation ${ }^{92}$ and as administered by the Treasury, ${ }^{93}$ contained no requirement that the choice of a third country be restricted in the first instance to market-economy countries at stages of development comparable to the SCE country in question. Moreover, nothing in the language of the 1974 amendments, nor in the legislative history, made any reference to the concept of comparability. In adding the comparability requirement, the argument goes, Treasury went beyond the authority given it by section $205(\mathrm{c}) .^{94}$

These contentions the Treasury properly rejected. Although both the Senate and the House Reports clearly indicate a congressional intent to give legislative approval to Treasury's pre-1974 practice, ${ }^{95}$ such a ratification is hardly inconsistent with the refinement contained in the new regulations. In its early approach to imports from SCE countries, the Treasury invented a procedure for which it had no clear authority under the Antidumping Act of

92 See 19 C.F.R. $\$ 153.5$ (1973).

93 In its discussion of comments submitted on the proposed regulations, Treasury alleged that in selecting third-country surrogates in the past, it had "attempted to select a country that is most like the exporting country." 43 Fed. Reg. 35,262, 35,263 (1978). For this alleged past practice the Treasury did not cite any cases, and one commenter argued persuasively that the case law contradicted the existence of a pre-1974 comparability standard. Memorandum of Westinghouse Electric Corp. on Proposed Amendments Pertaining to Merchandise from State-ControlledEconomy Countries 3-5 (May 22, 1978) [hereinafter cited as Westinghouse Memorandum] (copy on file with the University of Pennsylvania Law Review).

Even assuming that the Treasury had pursued an unannounced policy of selecting third countries on the basis of comparability, it is extremely unlikely that Congress was aware of such an obscure practice when it enacted $\$ 205(\mathrm{c})$ in 1974. Thus, the Treasury's revelation of its alleged past practice fails to counter the argument that the new regulations were precluded by the mandate of $\$ 205(\mathrm{c})$. No past practice is needed, however, to reconcile the new regulations with the statute. See text accompanying notes 95-107 infra.

94 Westinghouse Memorandum, supra note 93, at 1-3; Comments of Westinghouse Electric Corp. on Proposed Amendments Pertaining to Merchandise from State-Controlled-Economy Countries 9 (Feb. 15, 1978) [hereinafter cited as Westinghouse Comments] (copy on file with the University of Pennsylvania Law Review); Harley Davidson Comments, supra note 67, at 6-7.

95 The House Report read:

A new subsection (c) to $\$ 205$ is also added to adopt in the law the substance of the existing Treasury Department practice, as reflected in $\$ 153.5$ (b) of the Treasury's antidumping regulations (19 C.F.R. I53.5(b)) ... The amendment would confirm the Treasury practice under which the Secretary makes the necessary dumping determinations with respect to 
1921..$^{96}$ By filling in that lacuna and clearly expressing its intent to ratify Treasury's innovative use of administrative discretion, Congress did not curtail Treasury's discretion in continuing to deal responsibly with a slippery problem of international trade. ${ }^{27}$ It would be odd indeed if Congress's attempt to bestow its stamp of approval had the opposite effect of putting a straitjacket on Treasury's exercise of discretion. Applied generally, that obtuse interpretation of the legislative history of section 205(c) would stymie meaningful collaboration between Congress and the administrative arm of government. ${ }^{98}$

state-controlled-economy countries based on prices at which such or similar merchandise of a non-state-controlled-economy country is sold either for consumption in its home market or to other countries, or based on the constructive value of such or similar merchandise in a non-state-controlledeconomy country.

1973 H.R. REP., supra note 48 , at 72 .

The Senate Report stated:

The second amendment to section 205 , to be added as a new subsection (c), also unchanged from the House bill, would adopt, in substance, existing Treasury regulations concerning standards for comparison to be employed in investigations of merchandise imported from State-controlledeconomy countries. ... Accordingly, the amendments would confirm the existing Treasury practice ....

1974 S. Rep., supra note 13, at 174, reprinted in [1974] U.S. Code Cong. \& AD. NEws 7186, 7311.

96 Anthony, supra note 4, at 201-04. See text accompanying notes $32-43$ supra.

97 Both the House and the Senate Reports speak of adopting the existing Treasury practice, in substance. See note 95 supra. These reservations can be read as intending to leave the Treasury free to modify its regulations within the basic framework, endorsed by $\$ 205(\mathrm{c})$, of using third-country tests to determine foreign market value.

98 A useful analogy can be found in the doctrine that reenactment of a statute gives legislative sanction to its administrative interpretation. See generally K. DAvrs, Administrative Law Treatise $\$ 5.07$ (1958). There, too, the question has arisen whether such implied legislative adoption of a regulation prohibits the administrative agency from amending it without express authority from Congress. In Helvering v. Reynolds, 313 U.S. 428 (1941), the Supreme Court answered that question in the negative, noting that the prior administrative construction of the reenacted statute does not "become so embedded in the law that only Congress can effect a change. ... It gives way before changes in the prior rule or practice through exercise by the administrative agency of its continuing rule-making power." Id. 432 . K. DAvis, supra, at $\$ 5.10$.

Dean Griswold's thinking on the reenactment problem also supports the view taken here. Observing that, in general, the effect to be given to reenactment is "essentially one of administration rather than of law," Griswold, A Summary of the Regulations Problem, 54 Harv. L. REv. 398, 423 (1941), he remarked that "there must be freedom in working out the proper construction of a statute in the early days after its enactment." Id. 413. Even after an interpretive regulation has been established, it may be that the agency ought to be allowed to amend it prospectively, if not retroactively. Id. 416. That the Treasury was involved in just this process of "fine-tuning" its regulations in the early days following the enactment of $\oint 205$ (c) is apparent-the Department's decision to issue the regulations was prompted by its 
One variation on the legislative history argument contended that the regulations' preference for the constructed-value method when comparable prices are unavailable conflicted with a congressional preference, manifest in the legislative history, that domestic prices of United States producers be used whenever adequate price data from other market-economy countries cannot be found.99 The

experience in administering $\$ 205(\mathrm{c})$, and Treasury announced that it recognized the need to assess the effect of the amendments as soon as possible. 43 Fed. Reg. $35,262,35,263,35,264-65$ (1978). To the extent that the pre-1978 regulation had become established, Treasury's decision to apply the new regulation prospectively also conformed to the Griswold view. See note 75 supra.

991978 Antidumping Act Hearing, supra note 20, at 117, 122 (statement of Charles Owen Verrill, Jr.); Westinghouse Comments, supra note 94, at 11 .

This interpretation of $\$ 205(\mathrm{c})$, if adopted, would put the United States in violation of its international obligations as defined in the Multilateral Trade Negotiations (MTN) just concluded. Article 15 of the Agreement on Interpretation and Application of Articles VI, XVI, and XXIII of the General Agreement on Tariffs and Trade (Apr. 12, 1979), MTN AGREEMENTs, supra note 1 , at 30-31, allows the United States to calculate the foreign market value of SCE imports on the basis of a third-country price or constructed value, but limits the use of domestic United States prices by stating: "If neither prices nor constructed value ... provide an adequate basis for determination of dumping . . . then the price in the importing signatory [the United States price] . . . may be used." Id. 30 . Consistency with this MTN Agreement mandates that United States prices be employed as the determinants of foreign market value only if both third-country prices and constructed-value prove inadequate.

What effect should be given to Article 15 as a matter of domestic United States law is a question that admits of no easy answer. On the one hand, Congress clearly provided that any portion of the MTN Agreements it approved that conflicted with United States statutes would not take effect as domestic law. Thus if a court were to decide that Congress meant the Treasury to use United States manufacturers' prices before resorting to constructed value, $\$ 205$ (c) would conflict with Article 15 of the MTN Agreement, and the latter would fall.

On the other hand, the House Report states that Title I of the 1979 Act "encompasses those changes to the current countervailing duty and antidumping laws necessary or appropriate to the implementation of the international agreements on these subjects," 1979 H.R. REP., supra note 1 , at 45 . It also announces the intent of Congress "to make U.S. law and practice consistent with" the Antidumping Code of the General Agreement on Tariffs and Trade (GATT). Id. 59. Had Congress understood $\$ 205$ (c) to require use of United States prices before third-country constructed value, a priority inconsistent with the GATT Code, this statement of intent would lead one to expect a clarification of $\$ 205(\mathrm{c})$. That none was forthcoming suggests that $\$ 205(\mathrm{c})$ in 1974, and as reenacted in 1979, only allows use of United States prices when third-country-price and constructed value tests are inadequate.

This suggestion is not refuted by the disclaimer in the House Report, supra, at 76-77, denying any intent to approve or disapprove the new Treasury regulations. See note 23 supra. Although those regulations added the comparability criterion, they preserved the former regulations in allowing reference to United States prices only when price and constructed values do not provide an adequate basis for comparison. See text of pre-1978 regulation at note 89 supra. The House Report's caveat can best be understood as applying to the innovative aspects of the September, 1978, regulations. Had Congress wished to reserve its judgment on the pre-1978 regulation, it might easily have done so.

To summarize-although the question could be decided either way, the most sensible interpretation of Title I of the Trade Agreements Act of 1979 is that Congress intended to adopt Article 15's amendment of the GATT Anti-dumping 
legislative history on which the defenders of American industry here relied consists of a single sentence in the Senate Report, ${ }^{100}$ which establishes only an intent to "permit" and not an intent to require use of domestic United States manufacturers' prices in determining fair value. The 1978 regulations are thus consistent with this legislative history, because they provide for the use of those prices when all other prices or constructed-value referents fail.

A third statutory argument presented by representatives of American industry opposed to the new regulations centered on the use of the SCE country's actual physical inputs as the base data for constructed value. They contended that the purpose of section 205(c) was to prohibit consideration of the prices or costs of production in the SCE country. Calculating the costs of production on the basis of verified physical inputs was, according to these opponents, likewise within the Act's proscription. ${ }^{101}$

Responding to this criticism, the Treasury conceded that SGEcountry prices and costs are unreliable, but insisted that the actual physical inputs of production can be ascertained without difficulty and then valued in a market-economy country. ${ }^{102}$ Such a procedure, the Treasury maintained, effectuates the congressional intent to avoid reliance on artificial price and cost figures, while observing section 205(c)'s directive to find the "normal costs" of imported merchandise. ${ }^{103}$

The regulations' opponents did not lack a reply. Ingeniously they countered that in an SCE country, even the actual physical inputs are skewed because the mix of labor, raw materials, and energy that goes into manufacturing a product ordinarily depends on the relative cost of each factor. In a market-economy country, if labor is cheap and sophisticated machinery expensive, a manufacturer will use relatively more labor. In an SCE country, however, the mix of physical inputs is determined not by market forces, but by government decisionmaking, for instance, state subsidization of automated machinery. ${ }^{104}$ A calculus of costs based solely on these

Code and thought $\S 205(\mathrm{c})$, as elaborated by Treasury's pre- and post-1978 regulations, consistent with that Article. This interpretation also has the advantage of making United States domestic law consistent with international obligations. 1001974 S. REP., supra note 13, at 174, reprinted in [1974] U.S. ConE CoNG. \& AD. News 7186, 7311. See note 50 supra.

10143 Fed. Reg. 35,262, 35,263 (1978).

$102 \mathrm{Id}$.

10319 U.S.C. $\$ 164$ (c) (1976) (repealed, Trade Agreements Act of 1979, Pub. L. No. 96-39, Title I, $§ 106,93$ Stat. 144 (July 26, 1979); current version at id., Title I, $\$ 101$, to be codified as an amendment to the Tariff Act of 1930, at 19 U.S.C. $\$ 1677 b(c))$.

104 Westinghouse Comments, supra note 94, at 14-15. 
physical factors of production thus fails to account for the hidden costs of government intervention in the economy, as, for example, a rise in food prices to finance new technology for the export of lightbulbs. When Congress ruled that prices and costs of an SCE country should not be used to calculate fair value, it was argued, the prohibition extended as well to the actual physical inputs of production. ${ }^{105}$

As a statutory argument, this reasoning is perhaps too clever. At best it demonstrates that Congress would have been consistent had it banned reliance on physical inputs as well as prices. But Congress, it is clear, never considered that eventuality and meant only to confirm the existing practice of the Treasury. Especially when one considers the "principle that the construction of a statute by those charged with its execution should be followed unless there are compelling indications that it is wrong," 106 it would be difficult to say that the Treasury is mistaken in its understanding of what Congress meant to forbid in section 205(c). ${ }^{107}$

\section{B. Policy Objections}

In addition to the statutory arguments, the standard of comparability embraced by Treasury's recent regulations has also been subjected to a barrage of criticism on policy grounds. Questioning has focused on the use of per capita GNP as the criterion of comparable development, the availability of GNP figures for SCE countries, the assumption that countries at comparable stages of development have comparable internal costs and prices, and the decision to apply the comparability standard, not to comparable

$105 \mathrm{Id}$. Similarly it was argued that $\$ 205(\mathrm{c})$ was intended to prohibit use of GNP figures from SCE countries for the purpose of assessing comparability of economic development. INTERFACE ONE, supra note 5, at 186 (remarks of Richard O. Cunningham); Westinghouse Comments, supra note 94, at 12-13. See Westinghouse Memorandum, supra note 93, at 5-7. Yet no evidence that Congress gave any consideration to the reliability of such macroeconomic data was offered.

106 Miller v. Youakim, 440 U.S. 125, 144-45 n.25 (1979) (quoting Red Lion Broadcasting Co. v. FCC, 395 U.S. 367, 381 (1969) (footnote omitted)). Accord, Board of Governors of the Fed. Reserve Sys. v. First Lincolnwood Corp., 439 U.S. 234, 251 (1978).

107 As a matter of policy, the failure of the new approach to constructed value to include certain hidden costs of the SCE producer need not be a fatal flaw. Resource allocation, even in an SCE country, is not without limits. Moreover, marketeconomy-country producers have hidden costs, too, resulting from social legislation tax loopholes, government subsidies, and the like. Any estimate of constructed value is at best an approximation, and the question ought not to be whether the new method of calculation is a perfect one, but whether it permits a more accurate and fairer picture of the value of SCE imports than the former method of selecting


dress by Deputy Assistant Treasury Secretary Peter D. Ehrenhaft). See text accompanying notes $108-20$ infra. 
producers or industries in market-economy countries, but rather to comparable market countries as a whole.

The selection of per capita GNP as the chief criterion for comparing the development of free market and SCE countries was attacked as arbitrary on the ground that other recognized measures of economic development, such as the level of industrialization, yield conflicting results. ${ }^{108}$ According to this view, almost any level of development can be assigned to a given SCE country, depending upon the criterion chosen. That other indicia of development yield different results, however, does not impair the validity of Treasury's choice of per capita GNP. The point of selecting a comparably developed economy is to find a surrogate country in which costs and prices most nearly reflect the costs and prices of the SCE country. Per capita GNP has the virtue of correlating closely with the general level of wages, ${ }^{109}$ and wages, in general, make up the greater part of production costs. Unlike other criteria of development, such as the level of industrialization, per capita GNP can thus be used to identify the market-economy countries whose labor costs, and overall production costs, will be most comparable to the costs in the SCE country.

The availability of sufficient statistical data to determine the GNP of SCE countries has also been a subject of dispute. Critics of the regulations note that in contrast to market-economy countries, which report gross national product in accordance with the United Nations System of National Accounts, SCE countries report a net material product based on different kinds of data.110 While acknowledging that projections of GNP for SCE countries have been made, these same critics contend that such estimates are imprecise. On the other hand, economists who have addressed this question have concluded that any imprecision inherent in Western recalculations of GNP figures from SCE countries is not likely to be so

1081979 House MTN Hearings, supra note 19, at 106, 108 (statement of Charles Owen Verrill, Jr.); id. 112-15 (paper by Professor Stanislaw Wasowski, prepared for Harley Davidson Co.).

109 INTERFACE ONE, supra note 5, at 209 (remarks of Professor Franklyn D. Holzman); id. 231 (remarks of Richard O. Cunningham).

1101978 Antidumping Act Hearing, supra note 20, at 117, 127 (statement of Charles Owen Verrill, Jr.); Westinghouse Comments, supra note 94, at 12.

In recent years a number of projects have attempted to develop methods for comparing the GNPs of market-economy and SCE countries. The most ambitious study, undertaken by the United Nations Statistical Office and the University of Pennsylvania, and supported by the World Bank, began in 1968 and is now nearing completion. See A System of International Comparisons of Gross Product and Purchasing Power: Phase I (I. Kravis ed. 1975); International Conparisons of Reat Product and Purchasing Power: Prase II (I. Kravis ed. 1978). 
statistically significant as to detract from the viability of per capita GNP as a criterion of comparable development. ${ }^{111}$

Although greater statistical exactitude is desirable in this area, it is important to keep in mind the alternative methods of selecting a third country. The relevant question is not whether per capita GNP offers a perfect method of comparison, but whether it represents a significant advance over the former method of selecting a surrogate country virtually at random. ${ }^{112}$ Examined in this light, the imperfections in computing GNP figures for SCE countries do not undermine the value of Treasury's new regulations, especially when the availability of additional criteria, such as the level of infrastructure development, is taken into account.

A similar analysis suffices to rebut a third complaint directed at the per capita GNP test. Opponents of the regulations insisted repeatedly that the GNP criterion rested on the fallacious assumption that countries with comparable GNPs have comparable internal costs or prices.113 Although large differences in particular comparative advantages may not show up in gross figures, they can create severe distortions in particular price comparisons between countries. In mineral-rich nations like Saudi Arabia, for example, higher per capita GNP may coexist with relatively low internal prices. The likelihood of such distortions, according to this view, renders the per capita GNP test worthless as a tool for ascertaining the foreign market value of SCE products.

In its extreme form this argument is misleading. It is true that GNP levels do not accurately reflect the distribution of natural resources among countries. But per capita GNP is a reliable indicator of general wage levels, ${ }^{114}$ a major factor in production costs, ${ }^{115}$ especially for manufactured items. ${ }^{116}$ Moreover, the regulations do not restrict Treasury to this measure alone, but allow comparability to be determined from "generally recognized criteria," including "infrastructure development (particularly in the industry producing

111 INTERFace ONE, supra note 5, at 209 (remarks of Professor Paul Marer); id. 209-10 (remarks of Professor Franklyn D. Holzman); see Soltysinski, The United States Antidumping and Countervailing Duty Laws from a Socialist Economy Perspective 13-14 (July 21, 1978) (unpublished paper on file with the University of Pennsylvania Law Review).

112 INTERFACE ONE, supra note 5, at 175, 185 (address by Deputy Assistant Treasury Secretary Peter D. Ehrenhaft).

113 E.g., 1979 House MTN Hearings, supra note 19, at 106, 107-08 (statement of Charles Owen Verrill, Jr.); id. 114-15 (paper by Professor Stanislaw Wasowski, prepared for Harley Davidson).

114 See note 109 supra.

115 INTERface ONE, supra note 5, at 209 (remarks of Professor Franklyn D. Holzman).

116 Id. 229 (remarks of Professor Stanislaw J. Soltysinski). 
such or similar merchandise)." 217 By employing additional criteria of comparability, Treasury will be able to avoid the spectre of grossly distorted price and cost comparisons. Here, once again, a perfect comparison is not the issue, but rather a method that most closely approximates the real value of the imported goods. On this score, no one could reasonably doubt that a market-economy country of matching per capita GNP is a more likely candidate for a fair approximation than a third country selected arbitrarily.

Perhaps the most sophisticated policy argument against the comparability test adopted by the Treasury is that which would place the focus not on comparable economies, but on comparable producers. ${ }^{118}$ Treasury's test, the argument begins, is biased in favor of the SCE producer, because it allows the foreign market value of his goods to be computed in accordance with the lower prices or costs of a comparably developed economy, and not on the basis of the higher prices or costs prevailing in more advanced economies where a comparably sophisticated producer would normally be found. ${ }^{119}$ Sophisticated manufacturers are typically located in advanced market-economy countries because, there, decisions to invest in labor-saving equipment are private ones, spurred by high labor costs. Where labor is cheap, market forces militate against large capital investments in advanced plants. These market relationships, however, are replaced in the SCE country by government planning, which permits highly automated plants and cheap labor to exist side by side. When such a situation occurs, as it did in the Polish Golf Cart Case, Treasury's comparable-economy test gives the SCE producer the double benefit of higher efficiency and inexpensive labor. ${ }^{120}$ This "unfair" advantage to the SCE producer could be eliminated, according to this view, by basing the selection of a thirdcountry surrogate on the existence of a comparable producer or comparable industry.

The logic supporting the comparable-producer proposal provocatively illustrates section 205(c)'s potential for discriminating against SCE imports on ideological grounds. Instead of seeking to estimate the foreign market value of SCE goods, the comparableproducer test would deprive a country like Poland of its actual cost advantages on the theory that any cost advantage accruing to an

11719 C.F.R. $\$ 153.7$ (b)(1) (1979).

118 See 1979 House MTN Hearings, supra note 19, at 93, 100-01 (statement of Richard $O$. Cunningham); INTERFACE ONE, supra note 5, at 187-88 (remarks of Richard O. Cunningham).

119 See note 118 supra.

120 Id. 
SCE country by virtue of its nonmarket orientation must be disregarded as "unfair." In effect, such an approach to valuation would penalize SCE countries for departing from cherished free market principles and would erect an impermeable barrier to SCE imports.

It should be acknowledged that the policy underlying the comparable-producer proposal is not an incoherent one. No doubt ardent defenders of free enterprise could be found who would seriously maintain that, for instance, the low labor costs enjoyed by SCE producers are in theory illusory, and that the higher labor costs prevailing in more advanced market-economy countries constitute the SCE producer's true labor costs. Congress, however, in enacting section 205(c), gave no indication of embracing a theoretical approach to valuation so antagonistic to trade with SCE countries. It was concerned with the more mundane problem of calculating the actual value of SCE imports in the absence of reliable market prices and costs. That pragmatic attitude was also the essence of wisdom. In an increasingly complex and interdependent world economy, cold-war shibboleths adapted for protectionist uses may well close the doors to peace and prosperity.

\section{CONGLUSION}

The purpose of United States antidumping law is to discourage unfair price-discrimination practices in the importation of foreignmade goods into the United States. Because of the difficulty of ascertaining the foreign market value of imported goods, there is always a danger that antidumping measures will be subverted to protectionist designs. As a result, domestic markets characterized by excessive concentration, inefficient producers, or inflated prices may be shielded from the healthy competition of lower-priced imports.

This danger is especially acute in the application of the antidumping law to imports from state-controlled-economy countries. Because costs and prices in those countries are set more or less independently of market forces, the ordinary tests of foreign market value do not apply, and valuation is necessarily speculative. Experience with this problem in the Polish Golf Cart Case led the Treasury Department, in 1978, to promulgate new regulations which attempt a fairer and more rational valuation of SCE imports.

The new Treasury regulations, although admittedly imperfect, can withstand the criticisms levelled at them by American industrial interests. The statutory objections rely mainly on exaggerated and unconvincing perceptions of congressional intent, while the objec- 
tions based on policy focus on the regulations' potential problems without denying, or seriously confronting, the obvious inadequacies of the former rules. The one alternative approach advanced by these critics-a proposal that a third country be selected on the basis of a comparable producer-is a thinly disguised vehicle of protectionism, which would erect a barrier to all manufactured products imported from SCE countries.

The importance of the Treasury regulations cannot be overestimated. In order to improve the balance of payments and increase trade, countries like Poland will increasingly seek to sell in the United States market sophisticated, labor-intensive products that require large capital investment. The Polish Golf Cart Case marked the first time an SCE country was successful in pursuing such a course. ${ }^{121}$ If, given these economic realities, United States antidumping law is to be amended to discriminate against imports from countries of communist or socialist persuasion, the task belongs to Congress, and not to the executive branch or to the courts. ${ }^{122}$ Consistent with the national policy favoring free trade and the will of Congress as expressed in section 205 (c), Treasury's September, 1978, regulations take a much needed step towards fair and evenhanded application of the antidumping law to imports from SCE countries.

121 INTERFACE ONE, supra note 5, at 95-96 (remarks of Professor Stanislaw J. Soltysinski).

122 See AFL-CIO v. Kahn, [1979] 5 LAB. ReL. Rep. (24 Wage \& Hour Cas.) 162, 170 (D.C. Cir., June 22, 1979) (en banc), cert. denied, 99 S. Ct. 3107 (1979). In Kahn, the plaintiffs argued that the Council on Wage and Price Stability Act (COWPSA) deprived President Carter of authority to require government contractors to comply with wage and price guidelines. Chief Judge Wright, writing for the court en banc, found support for the President's procurement program in Congress's renewal of COWPSA in 1979 without significant modification. Although he noted that the legislative history of the 1979 extension demonstrated full Congressional awareness of the President's program and contained express assertions of an intent to withhold judgment on its validity, id. 169-70, Chief Judge Wright reasoned that, because "Congress can reverse incorrect Executive interpretations of its statutes and has used that power in the past,.... [i]n this context, a court could only in the most extreme case find that the Executive has violated the statute." Id. 170 (footnote omitted).

A similar approach to the reenactment of $\$ 205(\mathrm{c})$ in the Trade Agreements Act of 1979 would preclude a judicial finding that the original passage of $\$ 205(\mathrm{c})$ deprived the Treasury of authority to issue its 1978 regulations. Here the argument is even stronger than in $K a h n$, where Congress merely extended the COWPSA for an additional year without meaningful alterations, because the Trade Agreements Act of 1979 made extensive changes in the antidumping law, but preserved $\$ 205$ (c) intact. Although, as in Kahn, the legislative history evinces an express attempt to avoid the issue of the validity of an administrative action, see note 23 supra, Kahn teaches that these reservations should not be taken at face value. Rather, after $K a h n$, attempts by Congress to duck resolution of a controversy by passing the buck to the courts should be viewed, in all but the most extreme cases, as impliedly approving the questioned administrative practice. 